ENTREPRENEURSHIP AND SUSTAINABILITY ISSUES

ISSN 2345-0282 (online) http://jssidoi.org/jesi/

2021 Volume 8 Number 4 (June)

http://doi.org/10.9770/jesi.2021.8.4(10)
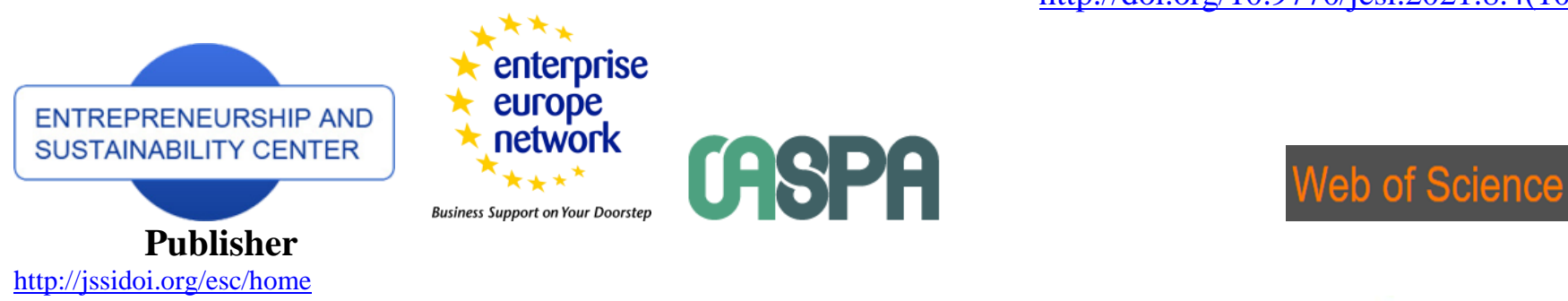

$\underline{\mathrm{http}: / / \text { jssidoi.org/esc/home }}$

\title{
1 Clarivate \\ Analytics \\ SIMPLE ADDITIVE WEIGHTING VERSUS TECHNIQUE FOR ORDER PREFERENCE BY SIMILARITY TO AN IDEAL SOLUTION: WHICH METHOD IS BETTER SUITED FOR ASSESSING THE SUSTAINABILITY OF A REAL ESTATE PROJECT
}

\author{
Nomeda Dobrovolskienė ${ }^{1}$, Anastasija Pozniak ${ }^{2}$ \\ 1,2 Vilnius Gediminas Technical University, Sauletekio al. 11, LT-10223 Vilnius, Lithuania \\ E-mails: ${ }^{\text {nomeda.dobrovolskiene@gmail.com; }{ }^{2} \text { anastasija.pozniak@vilntech.lt }}$
}

Received 18 November 2020; accepted 10 March 2021; published 30 June 2021

\begin{abstract}
In the real estate sector, sustainability assessment tools enable the transition to buildings with lower impacts on the environment, the economy and the society. A variety of multi-criteria decision-making (MCDM) methods has been proposed to address this problem. There is, however, no consensus on the method to be used in each assessment case. The paper presents an empirical application and comparison of two different MCDM approaches SAW (Simple Additive Weighting) and TOPSIS (Technique for Order Preference by Similarity to an Ideal Solution) to assessing the sustainability of a real estate project. 18 sustainability criteria weighted by experts formed the basis of sustainability assessment of a real estate project. The results of the study revealed a significant difference between the ranks obtained by SAW and TOPSIS. Moreover, the results of the MCDM sensitivity analysis showed that the TOPSIS method is more sensitive to changes in baseline data than the SAW method.
\end{abstract}

Keywords: multi-criteria decision-making; multiple-criteria decision-making; real estate project; sustainability assessment; sensitivity analysis; real estate sustainability index (RESI).

Reference to this paper should be made as follows: Dobrovolskienè, N., Pozniak, A. 2021. Simple Additive Weighting versus Technique for Order Preference by Similarity to an Ideal Solution: which method is better suited for assessing the sustainability of a real estate project. Entrepreneurship and Sustainability Issues, 8(4), 180-196. http://doi.org/10.9770/jesi.2021.8.4(10)

JEL Classifications: C00, Q01, M21, O22, L74, L85

\section{Introduction}

More than 30 years after the 1987 Brundtland Commission report, sustainability and its assessment have gained global recognition. Brundtland and subsequent reports (ICLEI 1994) promoted a holistic approach to sustainable development, taking into consideration economic, environmental and social effects. However, a review of the recent scientific literature shows a growing tendency to extend the concept of sustainability beyond three main dimensions (Vogt and Weber 2019; Purvis et al. 2019; Danish and Senjyu 2020; Venturini et al. 2020). This is reflected by increasing attention to the technological dimension, which plays an important role in developing new technologies that can minimize the impact on climate change and positively contribute to clean energy generation and consumption (Nowotny et al. 2018; Bulbul et al. 2018). All of this is of great relevance for the real estate 


\section{ENTREPRENEURSHIP AND SUSTAINABILITY ISSUES}

ISSN 2345-0282 (online) http://jssidoi.org/jesi/

2019 Volume 6 Number 4 (June)

http://doi.org/10.9770/jesi.2019.6.4(10)

sector, as it is responsible for approximately $40 \%$ of energy consumption and $36 \%$ of $\mathrm{CO} 2$ emissions in the European Union. In this paper, therefore, in order to assess the sustainability of a real estate project, the authors expand the concept of sustainability with the technological aspect.

Sustainability assessment is defined as a process by which decision-making is geared towards sustainability (Bond and Morrison-Saunders 2011, Zimek and Baumgartner 2019). Most authors agree that sustainability assessment is a multidimensional problem (Tupenaite et al. 2018). Therefore, sustainability-focused systems and assessment methods are developed (Dobrovolskienė 2016, Tupėnaitè et al. 2018). Among all certification systems and methods of sustainable building evaluation, the most popular ones are DGNB (German Sustainable Building Council), LEED (Leadership in Energy and Environment Design), and BREEAM (Building Research Establishment Environmental Assessment Method) (Li et al. 2017). These methods are based on a defined set of criteria, which are rated according to the criteria importance factor. These methods, however, are often criticized for ignoring economic and social concerns. Furthermore, some of these methods do not prioritize sustainability criteria with a view to facilitating decision-making (Drejeris and Kavolynas 2014; Tupenaite et al. 2018). The literature analysis also shows that sustainability indicators are effectively used to assess sustainability in the decision-making process (Dahl 2012; Pinter et al. 2012; Singh et al. 2012; Waas et al. 2014; Pereira 2015; Dobrovolskienè and Tamošiūnienè 2016). A wide variety of sustainability indicators have been developed for different stakeholders and applied in different contexts worldwide, using a broad range of methodologies (Dahl 2012; Pinter et al. 2012; Singh et al. 2012; Waas et al. 2014; Oliveira et al. 2016; Dobrovolskienė 2016; Ruiz et al. 2018; Kaklauskas et al. 2018; Chen et al. 2019; Dobrovolskienė et al. 2019; Bithas 2020; Lütje and Wohlgemuth 2020; Mohanty et al. 2020; Reid and Rout 2020; Binder et al. 2020; Carvalho et al. 2020). Thipparat and Thaseepetch (2013) presented a sustainability index, which was computed using VIKOR (in Serbian: Visekriterijumsko Kompromisino Rangiranje). This index is used to assess a sustainable research project. Dobrovolskienė and Tamošiūnienè (2016) proposed to measure the sustainability of a construction project by a composite index, which was developed using the SAW method. The index is composed of 15 sustainability criteria (four economic, five social and six environmental), which were rated as most important by construction practitioners. Arbolino et al. (2018) used the SAW method and the Principal Component Analysis model for designing the Industrial Environmental Sustainability Index. Krajnc and Glavic (2005) presented a model for constructing a composite sustainable development index that outlines company performance with regard to all three dimensions of sustainability, using analytic hierarchy process (AHP) to obtain the weights of the indicators. The sustainability sub-indices are then aggregated into the composite sustainable development index using the weighted average. Wang et al. (2012) proposed a novel method for developing a mixed model, which enables a comprehensive and objective integration of numerous criteria into a composite indicator using TOPSIS. EscrigOlmedo et al. (2017) adopted fuzzy TOPSIS to assess environmental, social and governance performance of companies. Firstly, synthetic indicators for each area of corporate sustainability have been elaborated and, secondly, investor preferences relating to environmental, social, governance and financial areas have been integrated to design a unique investment decision solution. Dobrovolskienè et al. (2019) designed a composite sustainability index for real estate projects, made up of 21 sustainability criteria (five economic equality, eleven environmental protection, and five equity indicators). The index was developed using the SAW method. Therefore, the use of MCDM methods is appropriate in the context of sustainability assessment, given their ability to aggregate numerous sustainability indicators into a single score (Tupenaite et al. 2018, El Gibari et al. 2019).

The aim of this article is to determine which MCDM method is better suited to assess the sustainability of a real estate project. These methods are (1) SAW (Simple additive weighting), and (2) TOPSIS (Technique for order preference by similarity to an ideal solution).

The article is structured in sections. Section 2 gives an overview of MCDM methods, together with sensitivity analysis on MCDM methods. In Section 3, a real estate sustainability index is constructed by means of two 


\section{ENTREPRENEURSHIP AND SUSTAINABILITY ISSUES}

ISSN 2345-0282 (online) http://jssidoi.org/jesi/

2019 Volume 6 Number 4 (June)

http://doi.org/10.9770/jesi.2019.6.4(10)

MCDM methods, and sensitivity analysis on these methods is carried out. The paper is finished with a number of conclusions in Section 4.

\section{Research methodology}

This section gives an overview of multi-criteria decision-making methods, a focus on the two MCDM methods adopted in this study (namely, TOPSIS and SAW). Moreover, this section also describes sensitivity analysis.

\subsection{Overview of multi-criteria decision-making methods}

Decision-making processes based on multiple criteria are commonly referred to as MCDM. Given their multidisciplinary nature, MCDM methods provide decision-makers with useful tools in the decision-making process (Taşabat and Özkan 2020). The choice of a multi-criteria decision-making method must take account of such issues as problem complexity, uncertainty rate, data type, and decision-maker preferences (Sabaei et al. 2015; Pasha et al.2020).

MCDM methods fall into two major groups (Zavadskas et al. 2014; Mardani et al. 2015; Dobrovolskienè et al. 2019; Jamei R. 2020):

- Multi-Objective Decision-Making (MODM) methods: An optimization problem is solved with an objective function while evaluating certain constraints.

- Multiple-Attribute Decision-Making (MADM) methods: Decision-making is intended for discrete comparison of alternatives.

MADM methods address problems with a discrete set of possible alternatives $\left(A=A_{1}, A_{2}, \ldots, A_{i}, \ldots, A_{m}\right)$. Alternatives mean possible different and targeted decisions specified by certain indicators $\left(X=X_{1}, X_{2}, \ldots, X_{j}, \ldots, X_{n}\right)$. These indicators reflect certain attributes of the alternatives, each of them describing one attribute of an alternative (Turskis et al. 2009; Liou and Tzeng 2012; Zavadskas et al. 2014; Yin and Shyur 2019).

MADM consists of the following steps (Turskis et al. 2009, Dobrovolskienè 2016): (1) development and selection of objective-related alternatives; (2) selection and analysis of criteria specifying the alternatives and rejection of related indicators; (3) selection of the key criteria and elimination of non-essential criteria; (4) determination of weights (significance) for each criterion; (5) aggregation of the criteria describing the alternatives; (6) selection of values of the criteria; (7) assessment the alternatives on the basis of the aggregate values of the criteria by applying a multi-objective function; (8) application of adopting a normative analysis method; (9) selection of the most acceptable alternative; and (10) where none of the alternatives are acceptable, other alternatives are sought, data collected, and the assessment cycle repeated for other alternatives, collecting data, and repeating the assessment cycle.

Such problems are usually solved in a matrix form. First, a problem-solving matrix is constructed with as many rows as the number of alternatives and as many columns as the number of criteria. The decision matrix is normalized so that numerical values of criteria have no measurement units. Then, the normalized decision matrix is assessed, i.e., the value of each criterion is multiplied by the significance of the corresponding criterion. The sum of the weights of the criteria must be equal to one (Dobrovolskienè 2016).

Based on the type of initial data used for the ranking of alternatives, MADM methods are divided into deterministic, stochastic and fuzzy set theory methods. MADM methods can also be classified on the basis of the number of decision-makers involved in decision-making. Taking into account the number of decision-makers, 


\section{ENTREPRENEURSHIP AND SUSTAINABILITY ISSUES}

ISSN 2345-0282 (online) http://jssidoi.org/jesi/

2019 Volume 6 Number 4 (June)

http://doi.org/10.9770/jesi.2019.6.4(10)

these include individual and group decisions (Simanavičienė 2011). Moreover, MADM methods are also classified according to information about indicators provided by the decision-maker (Zavadskas and Turskis 2011, Simanavičienè 2011, Dobrovolskienė 2016).

A wide range of MADM methods is currently used: GM (Geometric Mean), SR (Sum of Ranks), AHP (Analytic Hierarchy Process), SAW (Simple Additive Weighting), TOPSIS (Technique for Order Preference by Similarity to an Ideal Solution), VIKOR (in Serbian: Visekriterijumsko Kompromisino Rangiranje), COPRAS (Complex Proportional Assessment), ELECTRE (Elimination and Choice Expressing Reality), PROMTHEE (Preference Ranking Organization Method for Enrichment Evaluation) and others (Podvezko 2011; Ferreira et al. 2016; Dobrovolskienè 2016; Serrai et al. 2017; Mousavi-Nasab and Sotoudeh-Anvari, 2017; Yin and Shyur 2019; Broniewicz and Ogrodnik 2020; Pasha et al. 2020; Tavana et al.2020; Meshram et al. 2020; Jiang 2020; Sarband et al. 2020; Zhang et al. 2020). Each method has its own benefits and limitations, and there is no agreement yet as to which method is best suited for solving a problem of a certain type (Dobrovolskienè 2016; Ferreira and Santos 2016; de Farias Aires and Ferreira 2019). However, as the literature analysis showed, among all MADM methods, the most popular ones are SAW and TOPSIS (Podvezko 2011; de Farias Aires and Ferreira 2019; Dobrovolskienė et al.2019; Broniewicz and Ogrodnik 2020)

\subsubsection{Simple Additive Weighting}

Simple Additive Weighting is probably the best known and most widely used MADM method (Anupama et al. 2015; Mukhametzyanov and Pamucar 2018; Jamei R. 2020; Yasmin et al. 2020). The SAW method is also known as a scoring method. The basic logic of the SAW method is to obtain a weighted sum of performance ratings of each alternative over all attributes. An evaluation score is calculated for each alternative by multiplying the scaled value given to the alternative of that attribute with the weights of relative importance directly assigned by the decision maker followed by summing up of the products for all criteria (Mukhametzyanov and Pamucar 2018; Mukhlis et al. 2019; Putra et al. 2020).

When the SAW method is used to find the best alternative, normalization of variables is required according to the following formula so that the variables can be compared (Ibrahim and Surya 2019):

$$
\mathrm{n}_{\mathrm{ij}}=\frac{\mathrm{r}_{\mathrm{ij}}}{\max \left(\mathrm{r}_{\mathrm{ij}}\right)},
$$

where:

$r_{i j}$ - the value of $j$ alternative $i$ variable;

$\max \left(r_{i j}\right)$ - the highest value of $i$ variable.

However, as this method allows comparing only those variables that are maximizing, minimizing variables can be also transformed into the maximizing ones according to the formula (Dobrovolskiene 2016):

$$
\mathrm{n}_{\mathrm{ij}}=\frac{\min \left(\mathrm{r}_{\mathrm{ij}}\right)}{\mathrm{r}_{\mathrm{ij}}},
$$

where:

$\min \left(r_{i j}\right)-$ the lowest value of $i$ variable. 
In the final stage, the sum $S_{j}$ of the weighted normalized values of all indicators is calculated for every jth object according to the formula:

$$
\mathrm{S}_{\mathrm{j}}=\sum_{\mathrm{i}=1}^{\mathrm{m}} \omega_{\mathrm{i}} n_{\mathrm{ij}}
$$

where:

$\omega_{i}$ - the weight of $i$ variable;

$n_{i j}$ - the normalized value of $i$ variable for $j$ object.

$S_{j}$ falls between 0 and 1 .

After the application of these formulas for normalization of variables and its summation, the decision regarding the best alternative, containing the highest result (highest level of project sustainability) is selected.

\subsubsection{Technique for Order Preference by Similarity to an Ideal Solution}

The TOPSIS method is one of useful prioritization methods (Jamei R. 2020, Rathi et al. 2020). It was first proposed by Hwang and Yoon (1981) and further developed by Yoon (1987). Under this method, the best alternative has the shortest distance from the positive ideal solution (PIS) and the farthest from the negative ideal solution (NIS) (de Farias Aires and Ferreira 2019; Štirbanović et al. 2019; Rana and Patel 2020). TOPSIS method has a number of advantages such as (Mohd Khairuddin et al. 2015; Rana and Patel 2020): (1) ability to identify the best alternative fast; (2) simple, rational and comprehensive concept, rationality and comprehensibility; and (3) simple computational process that can be easily programmed into a spreadsheet. The TOPSIS method comprises the following steps (Satpathy et al. 2016):

The first step under the TOPSIS method is data normalization according to the following formula (Vafaei et al. 2018):

$$
\mathrm{n}_{\mathrm{ij}}=\frac{\mathrm{r}_{\mathrm{ij}}}{\sqrt{\sum_{\mathrm{j}=1}^{\mathrm{n}} \mathrm{r}_{\mathrm{ij}}^{2}}}
$$

The next step is multiplying the weight of each criterion by the normalized performance values according to the formula (Vafaei et al. 2018):

$$
\mathrm{W}_{\mathrm{ij}}=\omega_{\mathrm{ij}} \mathrm{n}_{\mathrm{ij}} \text {. }
$$

where:

$\omega_{i j}$ - the weight of $i$ alternative.

The following step of the process involves determination of the positive ideal $\left(A^{+}\right)$and the negative ideal solution $\left(A^{-}\right)$(Vafaei et al. 2018): 


$$
\begin{aligned}
& A^{+}=\left\{W_{1}^{+}, \ldots, W_{n}^{+}\right\}=\left\{\left(\operatorname{Max} W_{i j} \mid j \in J\right),\left(\operatorname{Min} W_{i j} \mid j \in J^{\prime}\right)\right\}, \\
& A^{-}=\left\{W_{1}^{-}, \ldots, W_{n}^{-}\right\}=\left\{\left(\operatorname{Min} W_{i j} \mid j \in J\right),\left(\operatorname{Max} W_{i j} \mid j \in J^{\prime}\right)\right\},
\end{aligned}
$$

where:

$J$ - positive factors or criteria (maximizing);

$J^{\prime}$ - negative factors or criteria (minimizing).

Then, the TOPSIS method requires calculating the separation of each alternative from the positive ideal solution $\left(D_{i}^{+}\right)$and the negative ideal solution $\left(D_{i}^{-}\right)$(Vafaei et al. 2018):

$$
\begin{aligned}
& D_{i}^{+}=\sqrt{\sum_{j=1}^{n}\left(W_{i j}-W_{j}^{+}\right)^{2}} \\
& D_{i}^{-}=\sqrt{\sum_{j=1}^{n}\left(W_{i j}-W_{j}^{-}\right)^{2}}
\end{aligned}
$$

The final step of the TOPSIS procedure is finding the performance score, i.e., the relative closeness to the ideal solution according to the following formula (Vafaei et al. 2018):

$$
\mathrm{C}_{\mathrm{i}}^{*}=\frac{\mathrm{D}_{\mathrm{i}}^{-}}{\mathrm{D}_{\mathrm{i}}^{+}+\mathrm{D}_{\mathrm{i}}^{-}}
$$

Where $C_{i}^{*}$ value falls between 0 and 1 , with higher values indicating better alternatives.

Hence, after computing these steps, the ranks of the preference order of alternatives can be determined and the alternative with the highest value, i.e., having the shortest distance from the ideal solution (highest level of project sustainability), is selected.

\subsection{Sensitivity analysis of MCDM methods}

Multi-criteria challenges solved by applying MCDM methods are usually based on subjective opinions of professional experts in the domain concerned. The results may therefore be biased and easily changed when minimal modifications are applied to criteria or the significance of criteria. Ultimately, the step of sensitivity analysis of MCDM methods is crucial in order to determine whether the result would change if the initial values of variables were altered (Simanavičienė and Ustinovičius 2011). The results obtained from sensitivity analysis are then compared with the initial results. This step is very important as it communicates the result, provides insights as to how the method behaves and its response to changes in the input variables (Borgonovo and Plischke 2016). Given the distributions of the values of criteria, a more sensitive or less sensitive method could be chosen in order to determine the rationality of the decision (Simanavičienè and Ustinovičius 2011). Therefore, it is necessary to determine and evaluate the sensitivity and reliability of MCDM methods. 


\section{ENTREPRENEURSHIP AND SUSTAINABILITY ISSUES}

ISSN 2345-0282 (online) http://jssidoi.org/jesi/

2019 Volume 6 Number 4 (June)

http://doi.org/10.9770/jesi.2019.6.4(10)

In literature, sensitivity analysis is depicted in two main ways:

1. When the sensitivity of a MCDM method is evaluated based on parameters and weights of criteria;

2. When the sensitivity of a MCDM method is evaluated based on deviations from initial values.

The main idea behind sensitivity analysis of MCDM methods is to identify factors contributing to the uncertainty of model results. Sensitivity analysis allows determining which parameters of a model are important and more accurate and thus would allow significantly reducing the uncertainty of model results and which parameters do not require any further refinement as they have little impact on the outcome (Simanavičienè and Ustinovičius 2011).

It should be noted that, according to the study performed by Simanavičienè and Ustinovičius (2011), the error of the initial variables by $\pm 5 \%$ is significant for the ranking of alternatives. Hence, one of the easiest ways to obtain a reliable MCDM outcome is to take into account possible errors in the initial values. This way, sensitivity analysis is performed based on the project's rank disposition when input variable $x i j$ changes by $\pm \lambda \%(\lambda= \pm 1 \%$; $\pm 2 \% ; \pm 3 \% ; \pm 4 \% ; \pm 5 \%$; . That is, by applying MCDM methods and having the initial results of indices, alternatives are ranked in such a way that the highest result of an index corresponds to rank number 1, while the project with the lowest index result corresponds to rank number 3. Hence, variables of alternatives within MCDM methods are changed by $\pm \lambda \%$ and the results are calculated once again by MCDM methods following the same procedure. When results are obtained, ranks are assigned again to each level of percentage change in order to show which MCDM method is more sensitive and at which percentage change the rank of alternatives will change. This is needed in order to understand the minimum modification of weights that is required to change the ranking (Operational 1995). Consequently, the method under which ranking of projects changes with the change in variables by $\pm \lambda \%$ is considered to be sensitive. However, the reliability of results is assessed by determining the most common rank of alternatives as it shows the reliability of the initial rank (Simanavičiene and Ustinovičius 2011). The studies performed by Zavadskas et al. (2007) showed that changes in certain criteria under the SAW method do not affect the final results of the solution, that is, this method is not sensitive to changes in parameters. The results also showed that the TOPSIS method is more sensitive compared to the SAW method with regard to changes in initial criteria (Zavadskas et al. 2007).

According to Mulliner et al. (2016), the ranking results of MCDM methods depend on the criteria that are considered within the analysis. As criteria and their ranking are usually based on the subjective opinion of experts, these rankings can vary moderately; therefore, the results and possible biases should be evaluated. Taking into consideration the subjective selection of criteria and assignment of weights, sensitivity analysis can be performed on the basis of the level of quantification of crosstalk between criteria and the ranking, which in turn indicates how the ranking of alternatives is going to change when the weights of criteria change (Mulliner et al. 2016). This is followed by the investigation of the most significant criterion in the analysis which is denoted to be the one that changes the ranking of alternatives with the smallest relative change in its weight. The study performed by Mulliner et al. (2016) showed that with the change in the level of weights by $\pm 50 \%$ the TOPSIS method outperforms other MCDM methods.

Also, as claimed by Simanavičienė and Ustinovičius (2011), sensitivity analysis can be performed taking into consideration only one parameter while all other parameters are fixed. It is usually performed when the correlation between variables and parameters is ignored and not analyzed. By default, the most sensitive criterion is the one whose weight or significance is the highest. Also, the most critical criterion can be determined. As already mentioned, this is the criterion that requires only a minimal change in its value significance in order to change the ranking of alternatives. Therefore, by applying the method of only one parameter or variable consideration, the decision-maker is able to consider one parameter at a time by applying minimal changes to the significance values of criteria. 
ENTREPRENEURSHIP AND SUSTAINABILITY ISSUES

ISSN 2345-0282 (online) http://jssidoi.org/jesi/

2019 Volume 6 Number 4 (June)

http://doi.org/10.9770/jesi.2019.6.4(10)

Moreover, sensitivity analysis can be performed by applying Monte Carlo modelling. Monte Carlo method is based on statistical modelling and is applied when it is not possible to obtain accurate results using a deterministic algorithm (Simanavičienè and Ustinovičius 2011). For this case, variables are usually generated on the basis from uniform distribution $\mathrm{X} \sim \mathrm{U}(\mathrm{a}, \mathrm{b})$ and normal distribution $\mathrm{X} \sim \mathrm{N}(\mu, \sigma)$. A uniform distribution is used by the authors to generate significance values for random indicators. Also, a decision matrix is formed using the values of criteria for alternatives. Consequently, using the significance values of the indicators provided by the experts, the rationality of alternatives is assessed by taking the generated matrices using the MCDM methods. Once the most common rank of an alternative has been determined, the frequency of the occurrence of that rank value is calculated (Simanavičienè and Ustinovičius 2011). This way, the reliability of results is evaluated. The studies performed by Simanavičiene and Ustinovičius (2011) showed that if the possible error rate is not less than $\pm 5 \%$, the ranking of alternatives changes with regard to both distribution laws. Moreover, in their study, the TOPSIS method was more sensitive compared to the SAW method with regard to both distributions.

In the light of the above, the weights of criteria are usually set subjectively with some biases and possible errors in setting values are not taken into account, which may cast doubts on the reliability of the decision outcome. Therefore, sensitivity analysis of MCDM methods is important for making decisions, for identifying the main criterion that affects the final ranking of alternatives and for determining the decision stability and risk. It appears from the scientific literature (Wolters and Mareschal 1995; Zavadskas et al. 2007; Simanavičienè and Ustinovičius 2011; Mulliner et al. 2016) that sensitivity analysis is usually performed on the basis of the significance of criteria but it is also recommended to conduct sensitivity analysis on the basis of the values of criteria.

\section{Comparison of SAW and TOPSIS methods}

This section presents a real estate sustainability index (RESI), which was constructed using SAW and TOPSIS methods. The index was compiled using the following algorithm (Fig. 1):

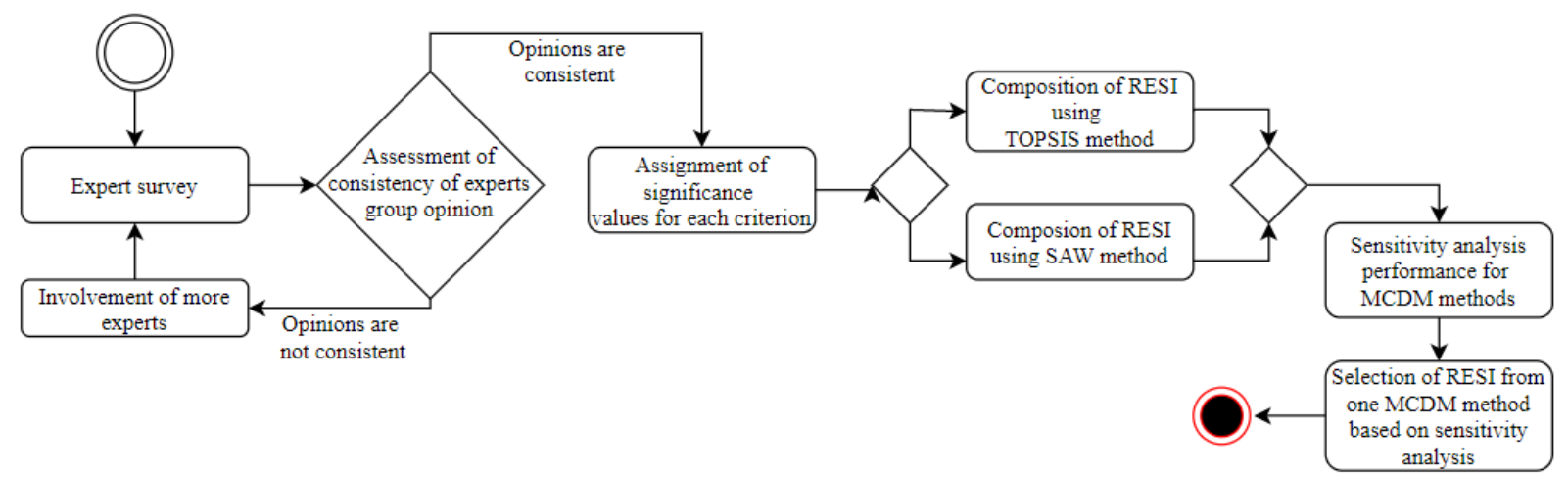

Fig. 1. RESI compilation algorithm

Source: authors

As can be seen from Figure 1, the process consists of six main steps:

1. Gathering information from the results of an expert survey;

2. Evaluating the consistency of group opinions;

3. Assigning significance values to each sustainability criterion based on the expert survey; 
4. Composing an index using two MCDM methods: SAW and TOPSIS;

5. Performing sensitivity analysis on both MCDM methods;

6. Selecting the final RESI from the indices generated by one of the MCDM methods.

In this paper, a two-stage expert survey was conducted to identify the most significant sustainability criteria for a real estate project. In the first stage, a survey form was designed and sent to 12 experts selected on the basis of their educational and professional background. The experts were asked to rate all criteria within each dimension on a 5-point scale ranging from $1=$ least significant to $5=$ most significant. Responses were received from nine experts, six of which have a PhD degree, with 5 to 19 years' experience related to project sustainability, one expert with a Master's degree and 5 years' practical experience, one professor with 10 years' experience, and one engineer with 15 years' practical experience in sustainable projects. The cut-off value was set at 3.5 to avoid having an excessive number of criteria, which could create biases and thereby influence results, leading to inappropriate evaluation of the final result (Dobrovolskiene et al. 2019). Consequently, only those criteria with the mean value equal to or higher than 3.5 were selected. As a result, a list of 18 significant sustainability criteria (5 environmental, 3 social, 5 economic, and 5 technological) was compiled, which was sent to the same nine experts in the second stage. The experts were asked to rank the criteria in the descending order of their significance, giving 18 points to the most significant criterion, and 1 point to the least significant one. The consistency of opinions was calculated using Kendall's concordance correlation coefficient (Ginevičius and Podvezko 2008):

$$
W=\frac{12 S}{m^{2}\left(n^{3}-n\right)}
$$

where:

$W$ is Kendall's coefficient of concordance;

$S$ is the sum of the deviation of ranks from the mean;

$n$ is the number of objects (criteria) $(i=1,2, \ldots, n)$;

$m$ is the number of experts $(j=1,2, \ldots, m)$.

The value was calculated to be 0.58 , which shows strong agreement between the expert opinions. Moreover, the reliability of the opinions was also calculated using Pearson's correlation coefficient ((12) formula):

$$
\left.\chi^{2}=m(n-1) W\right)
$$

is distributed by the $\chi^{2}$ distribution with $v=\mathrm{n}-1$ degree of freedom. At the selected level of significance $\alpha$, e.g., either 0.05 or 0.01 , the critical value $\chi_{k r}^{2}$ is taken from the table of the $\chi^{2}$ distribution with $v=\mathrm{n}-1$ degree of freedom. Where the value of $\chi^{2}$ calculated according to formula (12) is greater than $\chi_{k r}^{2}$, expert assessments are in agreement. The results indicate that the value of $\chi 2$ is higher than $\chi_{k r}^{2},(88.953>37.1565)$ at the significance level $\alpha=0.05$. Consequently, these coefficients confirm that the opinions of the experts are consistent and reliable and therefore can be relied on in further research.

In view of the responses from the experts, the weight for each criterion was determined. The results of the expert assessment and the type of each criterion (minimizing or maximizing) are set out in the table below (Table 1). 
ENTREPRENEURSHIP AND SUSTAINABILITY ISSUES

ISSN 2345-0282 (online) http://jssidoi.org/jesi/

2019 Volume 6 Number 4 (June)

http://doi.org/10.9770/jesi.2019.6.4(10)

Table 1. Weights and types of sustainability criteria

\begin{tabular}{|c|c|c|c|c|}
\hline $\begin{array}{c}\text { Dimension and } \\
\text { criterion }\end{array}$ & Code & $\begin{array}{c}\text { Weight coefficient in a } \\
\text { group }\end{array}$ & $\begin{array}{c}\text { Total weight } \\
\text { coefficient }\end{array}$ & Type \\
\hline Environmental & & 0.297 & & \\
\hline Emission of $\mathrm{CO} 2$ & $\mathrm{C} 1$ & 0.333 & 0.099 & Min \\
\hline Use of renewable energy & $\mathrm{C} 5$ & 0.241 & 0.071 & Max \\
\hline Waste management & $\mathrm{C} 7$ & 0.214 & 0.064 & Max \\
\hline $\begin{array}{l}\text { Post construction energy } \\
\text { consumption }\end{array}$ & $\mathrm{C} 12$ & 0.142 & 0.042 & Min \\
\hline Dust reduction & $\mathrm{C} 18$ & 0.070 & 0.021 & Min \\
\hline $\begin{array}{c}\text { Social } \\
\end{array}$ & & 0.170 & & \\
\hline $\begin{array}{l}\text { Safety and well-being of } \\
\text { workers }\end{array}$ & $\overline{\mathrm{C} 2}$ & 0.576 & 0.098 & 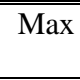 \\
\hline $\begin{array}{l}\text { Improvement of the life } \\
\text { quality }\end{array}$ & $\mathrm{C} 10$ & 0.271 & 0.046 & Max \\
\hline Safety of infrastructure & $\mathrm{C} 17$ & 0.153 & 0.026 & Max \\
\hline Economic & & 0.224 & & \\
\hline Quality control & C6 & 0.299 & 0.067 & Max \\
\hline "Time of construction & $\mathrm{C} 11$ & 0.191 & 0.043 & Min \\
\hline Reduction of direct costs & C13 & 0.186 & 0.042 & Min \\
\hline $\begin{array}{l}\text { Reduction of non-direct } \\
\text { costs }\end{array}$ & $\overline{\mathrm{C} 14}$ & 0.180 & 0.040 & Min \\
\hline $\begin{array}{l}\text { Economic benefit for the } \\
\text { region }\end{array}$ & $\overline{\mathrm{C} 15}$ & 0.145 & 0.032 & "Max \\
\hline $\begin{array}{l}\text { Technological } \\
\end{array}$ & & 0.309 & & \\
\hline $\begin{array}{l}\text { Employment of } \\
\text { innovative technologies }\end{array}$ & $\overline{\mathrm{CC} 3}$ & 0.278 & 0.086 & Max \\
\hline Overall project quality & $\overline{\mathrm{C} 4}$ & 0.236 & 0.073 & Max \\
\hline $\begin{array}{l}\text { Technical risks } \\
\text { throughout the project } \\
\text { life-cycle and feasibility }\end{array}$ & $\overline{\mathrm{C} 8}$ & 0.202 & 0.062 & Min \\
\hline $\begin{array}{l}\text { Degree of intellectual } \\
\text { property protection } \\
\text { (patents, trademarks, } \\
\text { copyrights) } \\
\end{array}$ & C9 & 0.194 & 0.060 & Max \\
\hline Cost of technology & C16 & 0.091 & 0.028 & Max \\
\hline
\end{tabular}

Source: authors

Moreover, indication of the criteria type leads to the step of criteria normalization which is based on the highest maximizing and lowest minimizing values out of three analyzed alternatives. For SAW method, normalization is calculated by applying (1) formula and (2) formula based on the negative (min) or positive (max) impact on sustainability and formula (4) is used to calculate normalized values for the TOPSIS method.

After normalization of variables, the next step is to derive index by applying SAW and TOPSIS methods. As mentioned earlier, SAW method is a summarization of weights, and thus, the sustainability index using this method is calculated based according to formula (3): 


$$
\begin{gathered}
R E S I=0.099 \mathrm{C}_{\mathrm{N} 1}+0.098 \mathrm{C}_{\mathrm{N} 2}+0.086 \mathrm{C}_{\mathrm{N} 3}+0.073 \mathrm{C}_{\mathrm{N} 4}+0.071 \mathrm{C}_{\mathrm{N} 5}+0.067 \mathrm{C}_{\mathrm{N} 6}+0.064 \mathrm{C}_{\mathrm{N} 7}+ \\
0.062 \mathrm{C}_{\mathrm{N} 8}+0.060 \mathrm{C}_{\mathrm{N} 9}+0.046 \mathrm{C}_{\mathrm{N} 10}+0.043 \mathrm{C}_{\mathrm{N} 11}+0.042 \mathrm{C}_{\mathrm{N} 12}+0.042 \mathrm{C}_{\mathrm{N} 13}+0.040 \mathrm{C}_{\mathrm{N} 14}+ \\
0.032 \mathrm{C}_{\mathrm{N} 15}+0.028 \mathrm{C}_{\mathrm{N} 16}+0.026 \mathrm{C}_{\mathrm{N} 17}+0.021 \mathrm{C}_{\mathrm{N} 18}
\end{gathered}
$$

The value of index falls between 0 and 1, where the value closer to 1 indicates higher sustainability level.

Also, RESI is composed using TOPSIS method which allows us to identify relative closeness to the ideal solution and thus, the sustainability index using this method is calculated based on (10) formula:

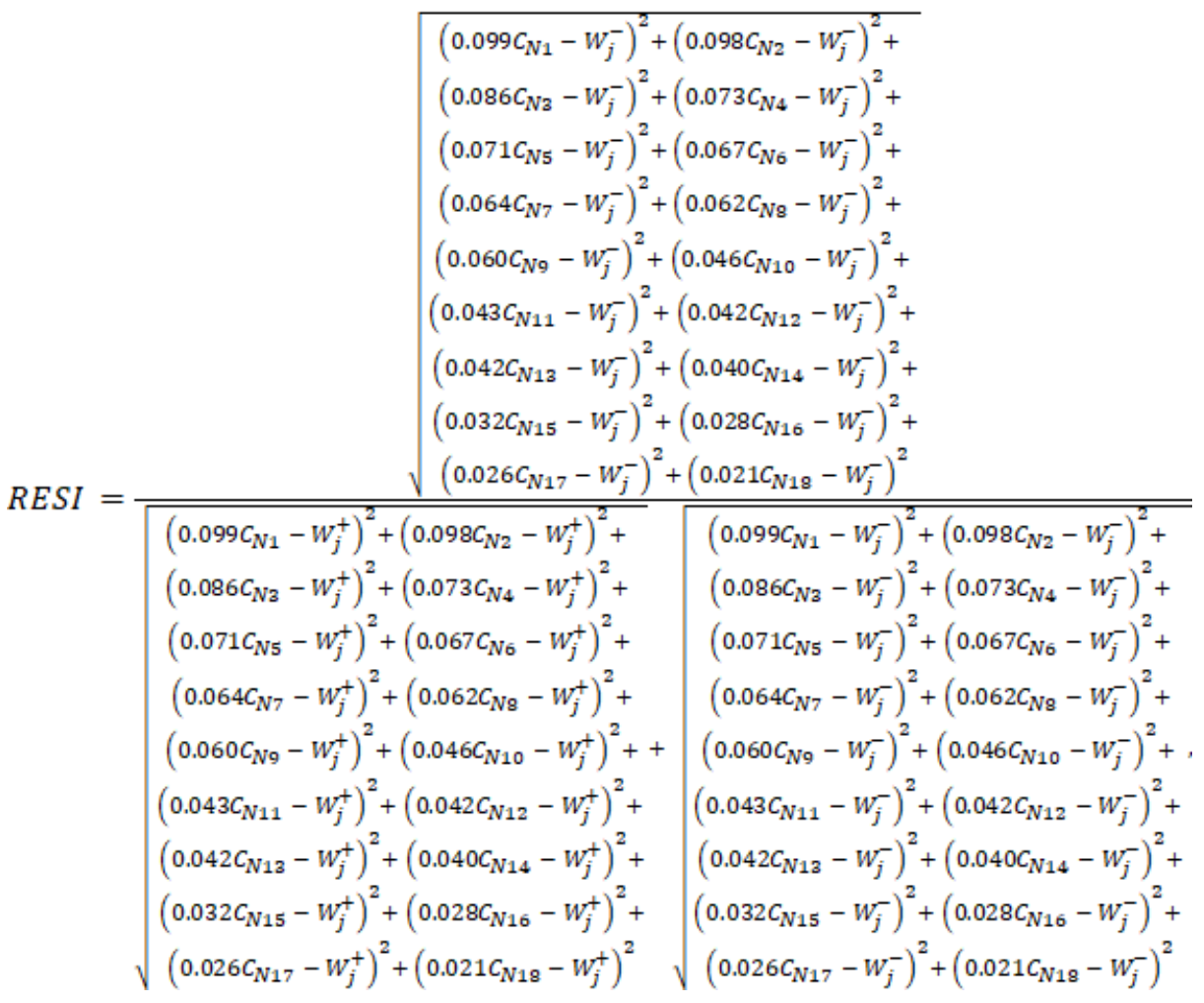

The value of index falls between 0 and 1, where value closer to 1 indicates higher sustainability level.

Sensitivity analysis on MCDM methods and indices is performed by evaluating the change in the project rank when the initial input variables xij are altered by $\pm \lambda \%$ (where $\lambda= \pm 1 \% ; \pm 2 \% ; \pm 3 \% ; \pm 4 \% ; \pm 5 \%$ ). Alternatives $\mathrm{A} 1, \mathrm{~A} 2$ and $\mathrm{A} 3$ correspond to the three analyzed real estate projects and the initial results are the values obtained from formula (13) and formula (14). These alternatives are ranked on the basis of the results obtained from these formulas, where the highest value corresponds to the highest rank of the alternative. Then, the sustainability of real estate projects is calculated once again by applying formula (13) and formula (14). Finally, the sustainability of real estate projects is recalculated by varying the inputs according to formula (13) and formula (14). The results are summarized in the table 2 below. 
Table 2. MCDM methods sensitivity analysis based on the project's rank change

\begin{tabular}{|l|c|c|c|c|c|c|}
\hline$\pm \lambda \%$ & \multicolumn{3}{|c|}{ SAW } & \multicolumn{3}{c|}{ TOPSIS } \\
\hline Alternatives & A1 & A2 & A3 & A1 & A2 & A3 \\
\hline Initial results & 0.551 & 0.518 & 0.755 & 0.421 & 0.363 & 0.602 \\
\hline Initial rank & 2 & 3 & 1 & 2 & 3 & 1 \\
\hline & \multicolumn{3}{|c|}{ Rank did not change } & \multicolumn{3}{c|}{ Rank changed } \\
\hline $1 \%$ & 2 & 3 & 1 & 3 & 1 & 2 \\
\hline $2 \%$ & 2 & 3 & 1 & 3 & 1 & 2 \\
\hline $3 \%$ & 2 & 3 & 1 & 3 & 1 & 2 \\
\hline $4 \%$ & 2 & 3 & 1 & 3 & 1 & 2 \\
\hline $5 \%$ & 2 & 3 & 1 & 3 & 1 & 2 \\
\hline
\end{tabular}

Source: authors

As Table 2 shows, sensitivity analysis was performed on two MCDM methods, SAW and TOPSIS. Changes in certain initial variables under sensitivity analysis on the SAW method do not affect the final solution and the rank ordering remains the same at all analyzed levels of percentage change. That is, the SAW method is not sensitive to changes in variables. On the other hand, under sensitivity analysis on the TOPSIS method, the rank ordering of the projects changes within 1\% of change. Therefore, the results of the MCDM sensitivity analysis show that the TOPSIS method is more sensitive to changes in baseline data than the SAW method.

The same results were observed by authors in other studies. For example, Simanavičienė and Ustinovičius (2011) performed sensitivity analysis by applying uniform and normal distributions. For both distributions, the TOPSIS method was more sensitive compared to the SAW method. In their study, in the case of uniform distribution, where the possible error rate of the initial variables is already above $2 \%$, the ranking of alternatives changed where the TOPSIS method was used.

\section{Conclusions}

The literature analysis revealed that MCDM methods are successfully utilized in creating sustainability assessment tools. It also showed that in order to determine whether the final result would be different in the case of changes in the initial values of variables, sensitivity analysis on MCDM methods must be performed.

In this paper, sustainability assessment of a real estate project was examined by using two different multipleattribute decision-making methods. This comparative study allowed identifying a suitable MADM algorithm that can be used to assess the sustainability of a real estate project. The results obtained by using TOPSIS and SAW showed that these two models produce different rankings. The sensitivity analysis on MADM methods revealed that the initial project rank of the SAW method, compared to the TOPSIS method, is more reliable $(100 \%$ reliability), as it remained unchanged at any analyzed level of percentage change.

The present research has some limitations, which will be addressed in future studies. The proposed sustainability assessment tool is based on the SAW and TOPSIS methods. In future research, the authors will use other multiple-attribute decision-making methods to verify the obtained results. 


\section{ENTREPRENEURSHIP AND SUSTAINABILITY ISSUES}

ISSN 2345-0282 (online) http://jssidoi.org/jesi/

2019 Volume 6 Number 4 (June)

http://doi.org/10.9770/jesi.2019.6.4(10)

Finally, the research makes a valuable contribution to the real estate sector and project management by equipping decision-makers with a tool that allows: 1) assessing the sustainability level of a real estate project; and 2) comparing projects with each other in order to decide on their financing.

\section{References}

Anupama, K. S. S. Gowri, S. S. Rao, B. P., \& Rajesh, P. (2015). Application of MADM algorithms to network selection, International Journal of Innovative Research in Electrical, Electronics, Instrumentation and Control Engineering, 3(6), 64-67.

Arbolino, R., De Simone, L., Carlucci, F., Yigitcanlar, T., \& Ioppolo, G. (2018). Towards a sustainable industrial ecology: Implementation of a novel approach in the performance evaluation of Italian regions. Journal of Cleaner Production, 178, $220-236$. https://doi.org/10.1016/j.jclepro.2017.12.183

Binder, C. R., Hutter, M., Pang, M., \& Webb, R. (2020). System science and sustainability assessment. Sustainability Assessment of Urban Systems, 30.

Bithas, K. (2020). A bioeconomic approach to sustainability with ecological thresholds as an operational indicator. Environmental and Sustainability Indicators, 6, 100027. https://doi.org/10.1016/j.indic.2020.100027

Bond, A.J. \& Morrison-Saunders, A. (2011) Re-evaluating sustainability assessment: aligning the vision and the practice. Environ Impact Assess Rev 31(1), 1-7. https://doi.org/10.1016/j.eiar.2010.01.007

Borgonovo, E., \& Plischke, E. (2016). Sensitivity analysis: A review of recent advances. European Journal of Operational Research, 248(3), 869-887. https://doi.org/10.1016/j.ejor.2015.06.032

Broniewicz, E. \& Ogrodnik, K. (2020). Multi-criteria analysis of transport infrastructure projects. Transportation Research Part D: Transport and Environment, 83, p.102351. https://doi.org/10.1016/j.trd.2020.102351

Brundtland, G.H. Our Common Future: Report of the World Commission on Environment and Develepoment. (1987). Available online: http://www.un-documents.net/ (accessed on 6 May 2020).

Bulbul, S., Ertugrul, G., \& Arli, F. (2018). Investigation of usage potentials of global energy systems. International Advanced Researches and Engineering Journal, 2(1), 58-67.

Carvalho, A. C. V. D., Granja, A. D., \& Silva, V. G. D. (2020). Use of a card game tool to capture end users' preferences and add sustainability value to social housing projects. Ambiente Construído, 20(1), 7-20. https://doi.org/10.1590/s1678-86212020000100360

Chen, C., Yu, Y., Osei-Kyei, R., Chan, A. P. C., \& Xu, J. (2019). Developing a project sustainability index for sustainable development in transnational public-private partnership projects. Sustainable Development, 27(6), 1034-1048. https://doi.org/10.1002/sd.1954

Dahl, A.L. (2012). Achievements and gaps in indicators for sustainability. Ecological indicators, 17, pp.14-19. https://doi.org/10.1016/j.ecolind.2011.04.032

Danish, M. S. S., \& Senjyu, T. S. (2020). Green Building Efficiency and Sustainability Indicators. In Green Building Management and Smart Automation (pp. 128-145). IGI Global. https://doi.org/10.4018/978-1-5225-9754-4.ch006

de Farias Aires, R.F. \& Ferreira, L. (2019). A new approach to avoid rank reversal cases in the TOPSIS method. Computers \& Industrial Engineering, 132, pp.84-97. https://doi.org/10.1016/j.cie.2019.04.023

Dobrovolskienè, N. (2016). Financial resource allocation in a project portfolio taking into account sustainability considerations. Doctoral dissertation, VGTU publisher „Technika“.

Dobrovolskienè, N. \& Tamošiūnienè, R. (2016). An index to measure sustainability of a business project in the construction industry: Lithuanian case. Sustainability, 8(1), p.14. https://doi.org/10.3390/su8010014 


\section{ENTREPRENEURSHIP AND SUSTAINABILITY ISSUES}

ISSN 2345-0282 (online) http://jssidoi.org/jesi/

2019 Volume 6 Number 4 (June)

http://doi.org/10.9770/jesi.2019.6.4(10)

Dobrovolskienė, N., Tamošiūnienė, R., Banaitis, A., Ferreira, F.A., Banaitienė, N., Taujanskaite, K. \& Meidutė-Kavaliauskienė, I. (2019). Developing a composite sustainability index for real estate projects using multiple criteria decision making. Operational Research, 19(3), 617-635. https://doi.org/10.1007/s12351-017-0365-y

Drejeris, R. \& Kavolynas, A. (2014). Multi-criteria evaluation of building sustainability behavior. Procedia-Social and Behavioral Sciences, 110, 502-511. https://doi.org/10.1016/j.sbspro.2013.12.894

El Gibari, S., Gómez, T., \& Ruiz, F. (2019). Building composite indicators using multicriteria methods: a review. Journal of Business Economics, 89(1), 1-24. https://doi.org/0.1007/s11573-018-0902-Z

Escrig-Olmedo, E., Rivera-Lirio, J. M., Muñoz-Torres, M. J., \& Fernández-Izquierdo, M. Á. (2017). Integrating multiple ESG investors' preferences into sustainable investment: A fuzzy multicriteria methodological approach. Journal of Cleaner Production, 162, 1334-1345. https://doi.org/10.1016/j.jclepro.2017.06.143

Ferreira, F. \& Santos, S. (2016). Comparing trade-off adjustments in credit risk analysis of mortgage loans using AHP, Delphi and MACBETH, International Journal of Strategic Property Management 20(1), 44-63. https://doi.org/10.3846/1648715X.2015.1105321

Ferreira, F.A., Spahr, R.W. \& Sunderman, M.A. (2016). Using multiple criteria decision analysis (MCDA) to assist in estimating residential housing values. International Journal of Strategic Property Management, 20(4), 354-370. https://doi.org/10.3846/1648715X.2015.1122668

Ginevičius, R. \& Podvezko, V. (2008). The problem of compatibility of various multicriteria evaluation methods. Business: Theory and practice 9(1): 73-80.

Hwang, C.L. \& Yoon, K. (1981) Multiple Attributes Decision Making Methods and Applications. Springer, Berlin Heidelberg, p. 225

ICLEI. Towards Sustainable Cities \& Towns: Report of the First European Conference on Sustainable Cities \& Towns; International Council for Local Environmental Initiatives: Freiburg, Germany, (1994).

Ibrahim, A. \& Surya, R.A. (2019). The Implementation of Simple Additive Weighting (SAW) Method in Decision Support System for the Best School Selection in Jambi. In Journal of Physics: Conference Series (Vol. 1338, No. 1, p. 012054). IOP Publishing. https://doi.org/10.1088/1742-6596/1338/1/012054

Jamei, R. (2020). Investigating the Mathematical Models (TOPSIS, SAW) to Prioritize the Investments in the Accepted Pharmaceutical. Advances in Mathematical Finance and Applications, 5(2), 1-15. https://doi.org/10.22034/amfa.2020.1880616.1312

Jiang, H., Zhan, J., Sun, B., \& Alcantud, J. C. R. (2020). An MADM approach to covering-based variable precision fuzzy rough sets: an application to medical diagnosis. International Journal of Machine Learning and Cybernetics, 1-27. https://doi.org/10.1007/s13042$\underline{020-01109-3}$

Kaklauskas, A., Zavadskas, E. K., Radzeviciene, A., Ubarte, I., Podviezko, A., Podvezko, V., ... \& Bucinskas, V. (2018). Quality of city life multiple criteria analysis. Cities, 72, 82-93. https://doi.org/10.1016/j.cities.2017.08.002

Krajnc, D., \& Glavič, P. (2005). How to compare companies on relevant dimensions of sustainability. Ecological Economics, 55(4), 551-563. https://doi.org/10.1016/j.ecolecon.2004.12.011

Li, Y., Chen, X., Wang, X., Xu, Y. \& Chen, P.H. (2017). A review of studies on green building assessment methods by comparative analysis. Energy and Buildings, 146, pp.152-159. https://doi.org/10.1016/j.enbuild.2017.04.076

Liou, J., Tzeng, G. (2012). Comments on "Multiple criteria decision making (MCDM) methods in economics: an overview", Technological and Economic Development of Economy, 18(4), 672-695. https://doi.org/10.3846/20294913.2012.753489

Lütje, A., \& Wohlgemuth, V. (2020). Tracking Sustainability Targets with Quantitative Indicator Systems for Performance Measurement of Industrial Symbiosis in Industrial Parks. Administrative Sciences, 10(1), 3. https://doi.org/10.3390/admsci10010003

Mardani, A., Jusoh, A., Nor, K., Khalifah, Z., Zakwan, N. \& Valipour, A. (2015). Multiple criteria decision-making techniques and their applications-a review of the literature from 2000 to 2014. Economic Research-Ekonomska Istraživanja, 28(1), 516-571. https://doi.org/10.1080/1331677X.2015.1075139 


\section{ENTREPRENEURSHIP AND SUSTAINABILITY ISSUES}

ISSN 2345-0282 (online) http://jssidoi.org/jesi/

2019 Volume 6 Number 4 (June)

http://doi.org/10.9770/jesi.2019.6.4(10)

Meshram, S.G., Alvandi, E., Meshram, C., Kahya, E. \& Al-Quraishi, A.M.F. (2020). Application of SAW and TOPSIS in Prioritizing Watersheds. Water Resources Management, pp.1-18. https://doi.org/10.1007/s11269-019-02470-x

Mohanty, S., Swain, C. K., Kumar, A., \& Nayak, A. K. (2020). Nitrogen Footprint: A Useful Indicator of Agricultural Sustainability. In Nutrient Dynamics for Sustainable Crop Production (pp. 135-156). Springer, Singapore. https://doi.org/10.1007/978-981-13-8660$\underline{2} \underline{5}$

Mohd Khairuddin, O., Mohd Naim, F., \& Noorul Shaiful Fitri, A.. (2015). The Malaysian seafarers psychological distraction assessment using a TOPSIS method. Int. J. e-Navig. Marit. Econ., 3, 40-50. https://doi.org/10.1016/j.enavi.2015.12.005

Mousavi-Nasab, S.H. \& Sotoudeh-Anvari, A. (2017). A comprehensive MCDM-based approach using TOPSIS, COPRAS and DEA as an auxiliary tool for material selection problems. Materials \& Design, 121, pp.237-253. https://doi.org/10.1016/j.matdes.2017.02.041

Mukhametzyanov, I., \& Pamucar, D. (2018). A sensitivity analysis in MCDM problems: A statistical approach. Decision making: applications in management and engineering, 1(2), 51-80. https://doi.org/10.31181/dmame1802050m

Mukhlis, H., Ayshwarya, B., Nguyen, P. T., Hashim, W., Maesaroh, S., Sagita, Y. D., ... \& Maseleno, A. (2019). Boarding house selection using SAW method. International Journal of Recent Technology and Engineering, 8(2 Special Issue 3), $1500-1505$. https://doi.org/10.35940/ijrte.B1275.0782S319

Mulliner, E., Malys, N. \& Maliene, V. (2016). Comparative analysis of MCDM methods for the assessment of sustainable housing affordability. Omega, 59, 146-156. https://doi.org/10.1016/j.omega.2015.05.013

Nowotny, J., Dodson, J., Fiechter, S., Gür, T. M., Kennedy, B., Macyk, W., ... \& Rahman, K. A. (2018). Towards global sustainability: Education on environmentally clean energy technologies. Renewable and Sustainable Energy Reviews, 81, $2541-2551$. https://doi.org/10.1016/j.rser.2017.06.060

Oliveira, E. C. B. D., Alencar, L. H., \& Costa, A. P. C. S. (2016). A decision model for energy companies that sorts projects, classifies the project manager and recommends the final match between project and project manager. Production, 26(1), 91-104. https://doi.org/10.1590/0103-6513.172314

Pasha, A., Mansourian, A., \& Ravanshadnia, M. (2020). A hybrid fuzzy multi-attribute decision making model to select road pavement type. Soft Computing, 24(21), 16135-16148. https://doi.org/10.1007/s00500-020-04928-2

Pereira, M. (2015). Participatory indicators of sustainability for the salmon industry: The case of Chile. Marine Policy, 51, 322-330. https://doi.org/10.1016/j.marpol.2014.09.010

Pintér, L., Hardi, P., Martinuzzi, A. and Hall, J. (2012). Bellagio STAMP: Principles for sustainability assessment and measurement. Ecological Indicators, 17, 20-28. https://doi.org/10.1016/j.ecolind.2011.07.001

Podvezko, V. (2011). Comparative analysis of MCDA methods SAW and COPRAS. Inžinerinė ekonomika, pp.134-146. http://dx.doi.org/10.5755/j01.ee.22.2.310

Putra, E., Hidayatuloh, S., Nguyen, P. T., Sasmita, K., \& Wibowo, M. C. (2020). Decision Support System for Proposing Scholarship Recipients to Best Students using SAW. International Journal of Control and Automation, 13(2), 103-109.

Purvis, B., Mao, Y., \& Robinson, D. (2019). Three pillars of sustainability: in search of conceptual origins. Sustainability science, 14(3), 681-695. https://doi.org/10.1007/s11625-018-0627-5

Rana, S. C., \& Patel, J. N. (2020). Selection of best location for small hydro power project using AHP, WPM and TOPSIS methods. ISH Journal of Hydraulic Engineering, 26(2), 173-178. https://doi.org/10.1080/09715010.2018.1468827

Rathi, R., Prakash, C., Singh, S., Krolczyk, G., \& Pruncu, C. I. (2020). Measurement and analysis of wind energy potential using fuzzy based hybrid MADM approach. Energy Reports, 6, 228-237. https://doi.org/10.1016/j.egyr.2019.12.026

Reid, J.; Rout, M. (2020). Developing sustainability indicators-The need for radical transparency. Ecological Indicators. $110,105941$. https://doi.org/10.1016/j.ecolind.2019.105941 


\section{ENTREPRENEURSHIP AND SUSTAINABILITY ISSUES}

ISSN 2345-0282 (online) http://jssidoi.org/jesi/

2019 Volume 6 Number 4 (June)

http://doi.org/10.9770/jesi.2019.6.4(10)

Ruiz, F., Cabello, J. M., \& Pérez-Gladish, B. (2018). Building Ease-of-Doing-Business synthetic indicators using a double reference point approach. Technological Forecasting and Social Change, 131, 130-140. https://doi.org/10.1016/j.techfore.2017.06.005

Sabaei D, Erkoyuncu J, Roy R. (2015). A review of multi-criteria decision-making methods for enhanced maintenance delivery. Proc CIRP 37:30-35. https://doi.org/10.1016/j.procir.2015.08.086

Sarband, E. M., Araghinejad, S., \& Attari, J. (2020). Developing an Interactive Spatial Multi-Attribute Decision Support System for Assessing Water Resources Allocation Scenarios. Water Resources Management, 34(2), 447-462. https://doi.org/10.1007/s11269-019$\underline{02291-y}$

Satpathy, A., Tripathy, S., Senapati, P. \& Brahma, M. (2016). Optimization of EDM process parameters for ALSiC-20\% SiC reinforced metal matrix composite with multi response using TOPSIS. Mater Today Proc., 4, 3043-3052. https://doi.org/10.1016/j.matpr.2017.02.187

Serrai, W., Abdelli, A., Mokdad, L. \& Hammal, Y. 2017. Towards an efficient and a more accurate web service selection using MCDM methods. Journal of computational science, 22, pp.253-267. https://doi.org/10.1016/j.jocs.2017.05.024

Simanavičienè, R. (2011). The sensitivity analysis of the quantitative multiple attribute decision making methods. Doctoral dissertation, VGTU publisher "Technika".

Simanavičienè, R., \& Ustinovičius, L. (2011). The Sensitivity Analysis of the Multiattribute Decision Making Methods by Monte Carlo Simulation. Information sciences, 56, 182-190. https://doi.org/10.15388/im.2011.0.3138

Singh, R. K., Murty, H. R., Gupta, S. K. \& Dikshit, A. K. (2012). An overview of sustainability assessment methodologies. Ecological Indicators, 15, 281-299. https://doi.org/10.1016/j.ecolind.2008.05.011

Štirbanović, Z., Stanujkić, D., Miljanović, I., \& Milanović, D. (2019). Application of MCDM methods for flotation machine selection. Minerals Engineering, 137, 140-146. https://doi.org/10.1016/j.mineng.2019.04.014

Taşabat, S. E., \& Özkan, T. K. (2020). TOPSIS vs. VIKOR: A Case Study for Determining Development Level of Countries. In Multi-Criteria Decision Analysis in Management (pp. 225-250). IGI Global. https://doi.org/10.4018/978-1-7998-2216-5.ch010

Tavana, M., Shaabani, A. \& Valaei, N. (2020). An integrated fuzzy framework for analyzing barriers to the implementation of continuous improvement in manufacturing. International Journal of Quality \& Reliability Management. https://doi.org/10.1108/IJQRM-06-2019-0196

Thipparat, T., \& Thaseepetch, T. (2013). An integrated VIKOR and fuzzy AHP method for assessing a sustainable research project. World applied sciences journal, 22(12), 1729-1738. https://doi.org/10.5829/idosi.wasj.2013.22.12.2787

Tupenaite, L., Kaklauskas, A., Lill, I., Geipele, I., Naimaviciene, J., Kanapeckiene, L. \& Kauskale, L. (2018). Sustainability assessment of the new residential projects in the Baltic States: A multiple criteria approach. Sustainability, 10(5), p.1387. https://doi.org/10.3390/su10051387

Turskis, Z., Zavadskas, E. \& Peldschus, F. (2009). Multi-criteria optimization system for decision making in construction design and management, Engineering Economics 1(61): 7-17.

Vafaei, N., Ribeiro, R.A. \& Camarinha-Matos, L.M. (2018). Data normalisation techniques in decision making: case study with TOPSIS method. International Journal of Information and Decision Sciences, 10(1),.19-38. https://doi.org/10.1504/IJIDS.2018.090667

Venturini, O. J., Júnior, J. C. F., Palacio, J. C. E., Batlle, E. A. O., Carvalho, M., \& Lora, E. E. S. (2020). Indicators for sustainability assessment of biofuels: Economic, environmental, social, and technological dimensions. In Biofuels for a More Sustainable Future (pp. 73-113). Elsevier. https://doi.org/10.1016/B978-0-12-815581-3.00004-X

Vogt, M., \& Weber, C. (2019). Current challenges to the concept of sustainability. Global Sustainability. https://doi.org/10.1017/sus.2019.1

Waas, T., Hugé, J., Block, T., Wright, T., Benitez-Capistros, F. \& Verbruggen, A. (2014). Sustainability assessment and indicators: Tools in a decision-making strategy for sustainable development. Sustainability, 6(9), 5512-5534. https://doi.org/10.3390/su6095512 


\section{ENTREPRENEURSHIP AND SUSTAINABILITY ISSUES}

ISSN 2345-0282 (online) http://jssidoi.org/jesi/

2019 Volume 6 Number 4 (June)

http://doi.org/10.9770/jesi.2019.6.4(10)

Wang, J., Wang, Z., Yang, C., Wang, N., \& Yu, X. (2012). Optimization of the number of components in the mixed model using multi-criteria decision-making. Applied Mathematical Modelling, 36(9), 4227-4240. https://doi.org/10.1016/j.apm.2011.11.053

Wolters, W.T.M., \& Mareschal, B. (1995). Novel types of sensitivity analysis for additive MCDM methods. European Journal of Operational Research, 81(2), 281-290. https://doi.org/10.1016/0377-2217(93)E0343-V

Yasmin, M., Tatoglu, E., Kilic, H. S., Zaim, S., \& Delen, D. (2020). Big data analytics capabilities and firm performance: An integrated MCDM approach. Journal of Business Research, 114, 1-15. https://doi.org/10.1016/j.jbusres.2020.03.028

Yin, L., \& Shyur, H. J. (2019). A Dynamic MADM Method for the Selection of a Big Data Service Provider. International Journal of Information and Management Sciences, 30(1), 57-71. https://doi.org/10.6186/IJIMS.201903_30(1).0004

Yoon, K. (1987). A reconciliation among discrete compromise solutions. Journal of the Operational Research Society, 38(3), 277286. https://doi.org/10.1057/jors. 1987.44

Zavadskas, E. K. \& Turskis, Z. (2011). Multiple criteria decision making (MCDM) methods in economics: an overview. Technological and Economic Development of Economy 17(2), 397-427. https://doi.org/10.3846/20294913.2011.593291

Zavadskas, E.K., Turskis, Z., Dejus, T. \& Viteikiene, M. (2007). Sensitivity analysis of a simple additive weight method. International Journal of Management and Decision Making, 8(5), 555. https://doi.org/10.1504/IJMDM.2007.013418

Zavadskas, E.K., Turskis, Z. \& Kildienė, S. (2014). State of art surveys of overviews on MCDM/MADM methods. Technological and economic development of economy, 20(1), 165-179. https://doi.org/10.3846/20294913.2014.892037

Zhang, Y., Fu, Z., Xie, Y., Hu, Q., Li, Z., \& Guo, H. A. (2020). Comprehensive Forecasting-Optimization Analysis Framework for Environmental-Oriented Power System Management-A Case Study of Harbin City, China. Sustainability $12,4272$. https://doi.org/10.3390/su12104272

Zimek, M., \& Baumgartner, R. J. (2019). Sustainability Assessment and Reporting of Companies. In Responsible Consumption and Production (pp. 1-13). Springer, Cham.

Dr Nomeda DOBROVOLSKIENE is an Associate Professor of the Department of Financial Engineering, Faculty of Business Management at Vilnius Gediminas Technical University, Lithuania. Her research interests are: Projects, Project Management, Project Portfolio, Project Portfolio Management, Sustainability, Multi-Criteria Decision-Making.

ORCID ID: orcid.org/0000-0002-1606-9980

Anastasija POZNIAK is a bachelor of finance. Her research interests are: Real Estate Projects, Project Portfolio Management, Sustainability, Multi-Criteria Decision-Making.

ORCID ID: orcid.org/0000-0003-1313-1280

Make your research more visible, join the Twitter account of ENTREPRENEURSHIP AND SUSTAINABILITY ISSUES: @Entrepr69728810

Copyright (C) 2021 by author(s) and VsI Entrepreneurship and Sustainability Center

This work is licensed under the Creative Commons Attribution International License (CC BY).

http://creativecommons.org/licenses/by/4.0/

cC) (i) Open Access 